\title{
Relasi Islam dan Masyarakat Etnis Tionghoa \\ (Studi Kasus: Komunitas Cina Benteng di Tangerang)
}

\author{
Bambang Permadi, SE, M.Hum. \\ UIN Syarif Hidayatullah Jakarta \\ bambang_permadi@ymail.com
}

\begin{abstract}
Abstrak
Komunitas Cina Benteng merupakan kelompok masyarakat etnis Tionghoa yang tinggal di Tangerang, Banten. Secara historis, orang Cina Benteng memiliki hubungan yang dekat dengan Islam meskipun kini banyak yang mengkonversi kepercayaannya menjadi non-muslim. Tujuan penelitian ini adalah untuk: 1) memahami struktur kebudayaan dan kehidupan masyarakat Cina Benteng; dan 2) mengetahui bagaimana tanggapan mereka terhadap Islam, baik sebagai doktrin maupun peradaban. Studi ini menunjukkan bahwa penerimaan Islam secara kultural oleh masyarakat Cina Benteng, tidak serta merta membuat mereka menerima Islam secara doktrin dan agama. Di samping itu, terdapat pula kesan yang konservatif terhadap kelompok Cina muslim..
\end{abstract}

Keywords: Chinese Muslim, Chinese ethnic, Tangerang.

\section{Pendahuluan}

Orang Cina Benteng merupakan sekumpulan orang Tionghoa yang awalnya mendiami pesisir pantai Tangerang (sekitar Teluk Naga) lalu merambah di sepanjang bantaran Cisadane sampai ke pusat kota Tangerang dan menyebar ke berbagai pelosok, ke Selatan (Karawaci, Legok, Cisauk dan Serpong) dan Ke Utara (Pasar Baru, Kedaung, Sepatan hingga Mauk). Mudahnya, sebutan Cina Benteng hanya berlaku untuk orang Tionghoa yang bermukim sejak lebih dari tiga generasi 
di Tangerang. ${ }^{1}$ Mereka yang tinggal bukan di Tangerang, maka bukan termasuk dalam sebutan Cina Benteng.

Penelitian ini adalah penelitian sejarah religio-antropologis, yakni dengan menyorot pada masalah sejarah etnis Cina Benteng di Tangerang. Fokus pembahasan pada interaksi komunitas Cina Benteng dengan Islam yang konotatif dengan pribumi. Islam dikabarkan disebarluaskan di Tanah Jawa oleh tokoh-tokoh Tionghoa atau keturunan Tionghoa yang didukung oleh penguasa Demak dan Mataram kemudian diterima dengan baik di Banten. Demikian pula di Tangerang yang sebelumnya merupakan wilayah bagian dari kerajaan Pajajaran. Kepercayaan pribumi yang kebanyakan adalah Sunda Wiwitan dan Hindu, secara massif beralih memeluk Islam. Islam menjadi sebuah peradaban pribumi.

Dalam proses islamisasi tanah Jawa, peran tokoh-tokoh Tionghoa tidak bisa dianggap kecil bahkan beberapa Wali Songo dipercaya merupakan tokoh dari dan keturunan Tionghoa. Hal lain yang menguatkan anggapan itu adalah artefak peninggalan berupa bangunan mesjid-mesjid yang ada di tanah jawa pada masa itu kebanyakan beratap tumpang yang merujuk pada arsitektur bangunan dari daratan Tiongkok. Peran yang demikian sentral dari orang-orang keturunan Tionghoa dalam menyebarkan Islam menjadikan perkembangan Islam di tanah Jawa menjadi sedemikian hebat sehingga mayoritas pribumi yang sebelumnya menganut Hindu, Budha, Kapitayan dan Sunda Wiwitan beralih memeluk Islam. Kenyataan ini tidak berbanding lurus dengan perkembangan Islam pada masyarakat Tionghoa, dalam hal ini komunitas Cina Benteng di Tangerang. Anggapan bahwa Cina Benteng dapat berbaur sempurna dengan pribumi menjadi dapat dipersoalkan. Orang Cina Benteng dapat menerima Islam sebagai budaya pribumi, itu sebabnya banyak perempuan pribumi yang mau dipersunting oleh lelaki Cina Benteng. Orang Cina Benteng ternyata belum bisa menerima Islam sebagai ajaran dan dogma yang harus

\footnotetext{
${ }^{1}$ Wawancara dengan Oey Tjin Eng.
} 
dijalankan. Ini dibuktikan dengan jumlah orang Cina Benteng yang Muslim menjadi minoritas di komunitasnya. Dengan latar belakang itu, penulis mencoba mengidentifikasi faktor apa saja yang menghambat islamisasi di kalangan Komunitas Cina Benteng.

Adapun tujuan penelitian ini adalah: 1) Memahami bagaimana struktur kebudayaan dan kehidupan sosial masyarakat Cina Benteng serta; dan 2) Mengetahui bagaimana tanggapan mereka terhadap Islam, baik sebagai doktrin maupun peradaban. Sedangkan, kegunaan penulisan ini adalah: 1) Memperkaya khazanah pengetahuan mengenai perkembangan komunitas Tionghoa di Tangerang; dan 2) Menjadi bahan bacaan untuk mengetahui bagaimana sesungguhnya anggapan orang Tionghoa terhadap Islam, khususnya di kalangan masyarakat Cina Benten.

Penelitian ini adalah penelitian mengenai interaksi antara masyarakat Cina Benteng di Tangerang dan relasinya dengan Islam. Islam di sini tentu saja mencakup aspek yang luas, bisa dikatakan mencakup doktrin dan peradaban. Untuk itu, diperlukan langkah-langkah penelitian yang perlu dijelaskan di bawah ini. Pertama, yakni pengumpulan sumber atau heuristik. Sumber yang dikumpulkan secara fisik terbagi dalam dua jenis yakni sumber tertulis dan sumber lisan. Sumber tertulis terdiri atas buku, dan lain sebagainya. Sedangkan sumber lisan adalah hasil dari observasi dan wawancaradengan beberapa orang atau tokoh yang dianggap menegerti. Sumber lisan di sini yakni penutur memberikan jawaban sesuai dengan pertanyaan yang diajukan, namun kedudukannya bukanlah sebagai pelaku sejarah. Kedudukannya adalah sebagai orang yang memberikan sejarah lisan dan amat penting sebagai salah satu rujukan utama. ${ }^{2}$ Selanjutnya peneliti mengumpulkan informasi berupa sumber primer dan sumber sekunder, baik berupa wawancara

\footnotetext{
${ }^{2}$ M. Dien, Madjid dan Johan, Wahyudhi,Ilmu Sejarah Sebuah Pengantar (Jakarta: Kencana,
} 2014) hlm. 122-123. 
langsung ataupun buku-buku, tulisan, artefak maupun situs yang dianggap dapat menggambarkan kondisi masyarakat.

Kemudian, materi-materi yang berhasil dikumpulkan akan masuk dalam tahap kritik sumber. Sumber yang telah melalui fase kritik, kemudian mencapai tahap interpretasi. Tidak bisa dipungkiri, luasnya tema kajian berikut interpertasi mengenainya adalah bagian yang tidak terpisahkan dari dinamika penulisan sejarah. $^{3}$ Tahap terakhir adalah penulisan, pembahasan mengenai judul yang diangkat, akan mengulas seputar relasi orang Cina Benteng dengan Islam yang dikonotasikan dengan pribumi, baik Islam sebagai agama maupun sebagai budaya. Pembahasan akan terfokus pada masalah yang diangkat ketika sampai pada bagian terakhir sebelum kesimpulan. ${ }^{4}$

\section{Islam sebagai Ingatan Sejarah Orang Tionghoa}

Islam merupakan agama yang ikut membangun peradaban orang Cina Benteng. Hal ini bisa dilihat dari pembangunan awal pemukiman Tionghoa Muslim saat masa pelayaran ketiga Cheng Ho. Namun, kenyataan historis ini tidak mampu menjadi pondasi yang kuat lahirnya masyarakat Islam yang bertahan dari generasi ke generasi hingga saat ini. Yang terjadi justru semakin banyak jumlah orang Cina Benteng yang beragama non-Islam.

Apa yang terjadi dalam tubuh masyarakat Cina Benteng ini dapat dikatakan sebagai anomali sejarah. Bagaimana mungkin jumlah penganut Islam mengalami penurunan, sedangkan di sebagian besar wilayah yang semula belum Islam lantas menjadi Islam, perkembangan jumlah penganutnya cenderung beranjak naik. Salah satu contohnyaadalah wilayah Jawa Timur yang semula dikuasai kerajaan-kerajaan beragama Hindu-Budha sejak sebelum abad 15.Penduduknya semakin banyak yang

\footnotetext{
${ }^{3}$ Kuntowijoyo, Pengantar IlmuSejarah (Yogyakarta: Bentang, 1995) ..., hlm. 100.

${ }^{4}$ Dudung,Abdurrahman,Metode Penelitian Sejarah (Tangerang: Logos Wacana Ilmu, 1999) hlm. 91-93.
}

35 | TamaddunVol. 7 , No. I, Januari - Juni 2019 
menganut Islam terhitung sejak naiknya pamor Demak hingga saat ini, penduduk Jawa mayoritas adalah beragama Islam. ${ }^{5}$

Kawasan Tangerang, ditinjau secara geografis, memang bukanlah pusat pemerintahan yang besar di masa lalu. Sejak zaman Pajajaran hingga penjajahan Belanda, wilayah ini dibayangi oleh kebesaran Kesultanan Banten dan Batavia yang terletak sejajar dengannya di wilayah pesisir utara Jawa Barat. Jumlah pemukim kawasan ini tentu saja tidak sebesar di Batavia atau di Banten. Melihat pada sejarah panjang masyarakat Tionghoa di sana, terdapat satu hal yang mencuat, yakni masalah pembauran antara pendatang dan pribumi. Dalam beberapa segi dikatakan bahwa orang Tionghoa di Tangerang adalah bagian yang tidak terpisahkan dari sebutan "Masyarakat pribumi", suatu sebutan yang sempat dipermasalahkan, ketika membicarakan kedudukan orang Tionghoa di negeri ini. ${ }^{6}$

Riwayat Cina Benteng memang tidak bisa disamakan dengan riwayat orang Tionghoa di tempat lain seperti Palembang, Semarang atau Surabaya yang banyak dicatat dalam laporan-laporan pada masa itu dan kajian-kajian mengenainya juga tidak sulit untuk didapatkan. ${ }^{7}$ Keberadaan masyarakat Cina Benteng secara historis masih menjadi suatu yang sumbernya masih tercecer di tinggalan geografis, cerita lisan, maupun catatan kolonial. Bisa dikatakan, sumbernya masih terserak dan masih sedikit menemukan ulasan atau penjelasan tertulis mengenainya.

Ketika membicarakan Islam dalam hal peradaban, agaknya akan berbeda ketika mendudukannya dalam pembicaraan dari segi keimanan. Islam di kalangan Cina Benteng dalam sejarahnya sudah sedemikian menjelma menjadi daur keseharian mereka, khususnya mereka yang memilih untuk meninggalkan

\footnotetext{
${ }^{5}$ M.C. Ricklefs, Sejarah Indonesia Modern, Terj. Dharmono Hardjowidjono (Yogyakarta: Gadjah Mada University Press, 1995) hlm. 55-56.

${ }^{6}$ Leo Suryadinata, Etnis Tionghoadan Nasionalisme Indonesia; Sebuah Bunga Rampai 19652008 (Jakarta: Kompas, 2010) hlm. 184.

${ }^{7}$ Salah satu sumber yang bisa dilihat mengenai sejarah orang Tionghoa di beberapa tempat di Jawa adalah H. J. De Graaf dkk, Cina Muslim di Jawa Abad XV dan XVI antara Historisitas dan Mitos (Yogyakarta: Tiara Wacana, 1998).
} 
kebudayaan Tionghoanya. Ini menimbulkan kesulitan tersendiri dalam mengidentifikasi mana yang telah termobilisasi ke dalam kebudayaan lokal dan mana yang justru mendirikan suatu komunitas Muslim namun tetap mempertahankan identitas dan tradisi ketionghoannya. Asimilasi memang sejak lama dijadikan metode mendekatkan orang Tionghoa dengan masyarakat pribumi. Saat mereka berpindah keyakinan menjadi Muslim, maka pada tahap itu mereka sudah melakukan sebagian dari proses asimilasi. Islam terbukti efektif meredam perbedaan status pribumi atau non-pribumi, keadaan yang sempat menjadi kenyataan kelam bagi orang-orang Tionghoa di negeri ini. Jika sudah menjadi Muslim, maka persaudaraan dengan Muslim lainnya dengan sendirinya terbentuk. ${ }^{8}$

Dalam bentangan sejarah Islam di Tiongkok Daratan, agama Islam hanya mempengaruhi sebagian kecil jalannya sejarah pemerintahan Tiongkok. Kalaupun ada tokoh-tokoh Tionghoa Muslim, seperti Cheng Ho, perannya dalam pengembangan Islam sampai kini belum banyak diketahui. Yang didapat dari mereka adalah kontribusinya memajukan Kekaisaran Tiongkok, sebagaimana yang dilakukan Cheng Ho tatkala berkunjung ke Nusantara atas nama Kaisar Tiongkok dan bukan didorong oleh maksud menyebarkan Islam.

Di beberapa kawasan Tiongkok, sebagai kekuatan politik, Islam berkembang dengan lambat. Seperti di Xinjiang, umat Islam di sana kerap terlibat dalam konflik, yang satu di antaranya adalah diakibatkan karena kebijakan pemerintah Beijing. Xinjiang adalah wilayah yang terletak di Tibet bagian Utara. Pada tahun 1884, Dinasti Ching (berkuasa 1644-1911) menamai daerah ini sebagai Xinjiang, menggantikan nama sebelumnya yakni Turkistan Timur. Masyarakat Xinjiang terdiri dari berbagai macam etnis seperti Uyghur, Hui, Kazakh, Kyrgiz, Tajik, Uzbek dan Tatar. Identitas mereka lama kelamaan melebur menjadi sebuah bangsa yang diikat dengan kesamaan agama, yakni Islam. Dinasti Ching banyak

\footnotetext{
${ }^{8}$ Abdul Baqir Zein, Etnis Cina dalam Potret Pembauran di Indonesia (Jakarta: Prestasi Insan Indonesia, 2000) hlm. 94.
} 
melakukan kebijakan adu domba dalam memecah belah persatuan Muslim. Etnis beragama Islam kerap terlibat pertikaian dengan orang Mongol, Han, dan Tibet yang kesemuanya dilakukan untuk mencapai superioritas bangsa satu atas yang lainnya. Pada prakteknya, permusuhan ini membuat mereka berada dalam keadaan yang semakin lemah. Saat Dinasti ini memimpin, terdapat beberapa pemberontakan yang diinisiasi oleh etnis muslim kepada pemerintah pusat, seperti Perang Lanchu, Chekamo, Sinkiang (Xinjiang/Turkistan Timur), Yunan dan Shansi. ${ }^{9}$

Di Indonesia kaum Tionghoa juga mengalami tekanan. Akar-akar represi terhadap orang Tionghoa terjadi pada masa kolonial. Penggolongan bangsa Tionghoa sebagai warga koloni kelas dua, menyebabkan mereka harus puas duduk sebagai warga yang mendapatkan pelayanan di bawah orang Eropa. Lahan-lahan bisnis yang terbuka lebar nyatanya tidak mampu mengalihkan perhatian mereka untuk menjadi warga setingkat orang Eropa. Kekerasan tahun 1740, begitu membekas di hati mereka sebagai salah satu bentuk diskriminasi ras yang dilakukan pemerintah Belanda saat itu. Alasan tersebut mendorong mereka berlomba-lomba menjadi warga koloni kelas satu, sesuatu yang sebenarnya tidak diinginkan Belanda. Alih-alih mendapat status itu, mereka justru semakin dikurung dalam "ketionghoaan" mereka. Maksudnya, adalah mereka diharuskan menggunakan atribut Tiongkok, seperti baju twikkif dan memelihara kuncir. Mereka yang menginginkan status layaknya orang Eropa biasanya didorong oleh naluri gengsi atau keinginan untuk mengadopsi kebudayaan Eropa secara radikal. ${ }^{10}$

Terdapat semacam reaksi berseberangan ketika orang Belanda memandang agama orang Tionghoa. Jika dalam bidang perniagaan mereka begitu menganggap tinggi kedudukan mereka, maka hal yang sebaliknya terjadi saat mereka melihat kepercayaan orang Tionghoa. K. Gutzlaff, rohaniawan Belanda tahun 1850-an,

\footnotetext{
${ }^{9}$ Dhurorudin Mashad, Muslim di Cina (Jakarta: Pensil 324, 2006) hlm. 5-6.

${ }^{10}$ Onghokham, Anti Cina, Kapitalisme Cina dan Gerakan Cina; Sejarah Etnis Cina di Indonesia (Depok: Komunitas Bambu, 2008) hlm. 57-58.
}

38 | TamaddunVol. 7 , No. I, Januari - Juni 2019 
menyebut bahwa banyak orang Tionghoa yang sejak lama menetap di Hindia Belanda, hidup jauh dari pendidikan, tidak beradab dan penuh dengan dosa. ${ }^{11}$ Pernyataan ini sedikitnya mengindikasikan betapa orang Tionghoa bukan sekedar mengalami represi di bidang politik, namun juga di bidang pendidikan dan agama.

Dalam keadaan itu, bagi sebagian kelompok yang memang terbiasa menjalankan tradisi Tionghoa Daratan bukanlah masalah yang berat. Kecuali pada pajak konde yang menuntut mereka membayar lebih karena disinyalir Batavia sempat menjadi tempat pelarian dari orang Tiongkok saat Dinasti Manchu berkuasa. Ditekan secara status kenegaraan, nyatanya tidak membuat mereka membuat aksi perlawanan, sebagian dari mereka merasa nyaman dengan budaya dan tradisi Tionghoa yang kental, sehingga membuat dakwah Islam di lingkungan mereka sulit berkembang. Ini adalah salah satu poin penting yang menjadi alasan mengapa perkembangan jumlah Muslim semakin menurun di kalangan masyarakat Tionghoa, seperti yang terlihat pada masyarakat Cina Benteng.

Warga Cina Benteng yang masih bertahan dalam tradisi ketionghoannya, termasuk dalam aspek keagamaannya, adalah mereka yang bernenek moyang kelompok di atas. Jikapun ada, maka karena faktor hidayah, atau karena kerelaan orang per orang Cina Benteng memeluk Islam, melanjutkan agama orang tua (ibu) atau karena faktor pernikahan. Bisa dikatakan, Islam belum mampu berbicara banyak dalam mendorong perpindahan agama secara massal di tubuh masyarakat Cina Benteng. Ritual-ritual yang dilakukan suatu agama dapat mempererat ikatan sosial di antara mereka. Agama adalah suatu system kepercayaan dengan perilakuperilaku yang utuh dan selalu dikaitkan dengan yang sakral, yaitu sesuatu yang terpisah dan terlarang. Yang sakral inilah yang kemudian menyatukan umatnya dalam satu komunitas moral tempat mereka memberikan kesetiaannya. ${ }^{12}$ Dalam hal

\footnotetext{
${ }^{11} \mathrm{~K}$. Gutzlaff, Aan mijne mede-christenen in Nederland (Amterdam: Loman Jr, 1850) hlm. 2.

${ }^{12}$ Daniel L. Pals, Seven Theories Of Religion Terj : Inyiak Ridwan (Jogjakarta :IRCiSoD, 2011) hlm. 145.
} 
ritual-ritual keagamaan orang Tionghoa dan demikian juga agama pribumi yang diwakili Islam sama-sama melakukan berbagai ritual yang pada akhirnya mampu menyatukan ukuwah diantara mereka.

Orang Tionghoa, sejak ketika masih di Tiongkok Daratan, adalah etnis yang amat dekat dengan kebudayaan leluhur. Peran pemerintah dalam kehidupan mereka tidak banyak berpengaruh. Rakyat Tiongkok menganggap keberadaan pemerintah, baik ketika masa kekaisaran serta memasuki fase negara modern tidak lebih adalah penengah dari pihak-pihak yang bertikai. Negara tidak hadir di setiap momen kehidupan rakyat. Negara dianggap sebagai sesuatu yang amat jauh dari kehidupan orang Tionghoa kebanyakan. ${ }^{13}$ Menginjak pasca kemerdekaan, orang Tionghoa di Jakarta dan sekitarnya justru disibukkan oleh perbedaan sikap berpolitik. Sebagian dari mereka mendukung lahirnya Republik dan menjalani apa yang kemudian ditetapkan pemerintah yang berkuasa. Yang lain terjebak dalam perbedaan politik tanah nenek moyang, antara mendukung Kuomintang atau gerakan Komunis Mao. Kelompok yang lain merasa di Jakarta atau di Indonesia pada umumnya, mereka hanya ingin menjalankan bisnis dan tidak berkeinginan untuk terlibat dalam haru biru politik. ${ }^{14}$ Perpecahan sudut pandang ini sedikit banyak membawa pengaruh pada semakin asingnya wacana keislaman dalam kehidupan mereka.

Ekonomi, benar-benar dimaknai sebagai pelarian yang menguntungkan bagi orang Tionghoa. Catatan episode panjang penderitaan mereka, seakan hilang terhapus seiring dengan semakin maju usaha-usaha yang dilakukan mereka. Arti agama tidak lebih hanya sematan, yang urgensinya tidaklah terlalu signifikan dalam kehidupan mereka. Namun, tentu tidak seluruh orang Tionghoa dapat sukses dalam usaha bisnisnya, banyak pula di antara mereka yang hidup di bawah garis kemiskinan seperti yang dialami banyak orang Cina Benteng.

${ }^{13}$ H.G. Creel, Alam Pikiran Cina; Sejak Confusius sampai Mao Zedong, Terj. Soejono Soemargono (Yogyakarta: Tiara Wacana, 1990) hlm. 253.

${ }^{14}$ Susan, Blackburn, Jakarta Sejarah 400 Tahun, Terj. Gatot Triwira (Depok: Komunitas Bambu, 2012) hlm. 218. 


\section{Islam sebagai pribumisasi orang Tionghoa}

Pada tanggal 25 Mei 2016, peneliti berkesempatan menelusuri jejak-jejak masa lalu Cina Benteng di kawasan muara Tanjung Burung, Tangerang. Di bantaran sungai sebelah barat dan timur,masih banyak dijumpai pemukiman orang Cina Benteng. Sebagian besar dari mereka masih menganut kepercayaan Tionghoa, sedangkan yang menganut Islam berada dalam jumlah yang lebih kecil. Pertanian dan perikanan serta perdagangan masih menjadi mata pencaharian kebanyakan dari mereka. Sungai Cisadane yang membelah pemukiman ini masih dimanfaatkan sebagai jalur transportasi air, kendati kapal-kapal yang melintas tidak terlalu besar.

Di masa lalu, sekitar kawasan ini dikenal sebagai kawasan produksi dan perbaikan kapal. Lokasinya yang dekat dengan kawasan pesisir, mampu diterjemahkan penduduknya sebagai kesempatan menciptakan lapangan kerja yang bersinggungan dengan lokus geografis yang mereka tempati. Di daerah itulah, diperkirakan, Utusan Laksamana Cheng Ho yang mendarat di pantai Tangerang kemudian bermukim. Hal ini mengingat daerah tersebut adalah pemukiman Cina Benteng yang tertua di Tangerang, selain juga melihat posisi pemukiman ini yang berada di kawasan pantai, wilayah yang memang di masa lalu kerap ditinggali para pendatang asing. ${ }^{15}$

Prosentase jumlah pemukim keturunan dan pribumi sekitar $60-40^{16}$. Beberapa Tinghoa keturunan bahkan menyandang jabatan sebagai ketua Rukun Tetangga (RT) maupun ketua Rukun Warga (RW). Sepintas, atribut-atribut ketionghoaan sudah sangat jarang dijumpai dalam keseharian mereka. Bahasa yang digunakan pun adalah Sunda dan bukan bahasa Hakka. Memang, tidak ada citra dominan yang muncul bahwa daerah itu didiami mayoritas orang peranakan. Hal

\footnotetext{
${ }^{15}$ Wawancara dengan Oey Tjin Eng.

${ }^{16}$ Wawancara dengan Tan Wan Chang, Penjaga Vihara Atta Naga Vimutti, Desa Tanjung Burung, Kec. Teluk Naga.
}

41 | TamaddunVol. 7 , No. I, Januari - Juni 2019 
berbeda jika kita benar-benar mengamati dan bertanya kepada beberapa penduduk setempat mengenai masa lalu tempat ini. ${ }^{17}$

Muslim Tionghoa, oleh sebagian kalangan, dinilai telah menjadi orang Indonesia seutuhnya. Junus Jahja menyebutkan bahwa dengan masuknya orang Tionghoa ke Islam, maka dengan sendirinya ia mendapatkan identitas keindonesiaannya. Ia meyakini bahwa Islam merupakan faktor pemersatu umat, terlepas dari etnis mana ia berasal. Seorang Tionghoa yang telah muslim, tidak harus tidak mengakui ketionghoaannya. Junus berkeyakinan bahwa Islam menjadi solusi tepat untuk memecahkan masalah identitas Tionghoa. Lewat yayasan yang pernah didirikannya pada 1981 bernama Yayasan Ukhuwah Islamiyah, ia mendakwahkan pesan positif ajaran Islam. Ia meyakini, sebenarnya tidaklah ada persinggungan antara agama, etnis dengan identitas kebangsaan. Masalah yang dihadapi Tionghoa yakni berupa peminggiran politik dan sosial,agaknya bisa sedikit demi sedikit tertanggulangi, apabila mereka masuk Islam. Setidaknya dengan memeluk Islam, mereka sudah menjadi bagian umat Islam indonesia. ${ }^{18}$

Salah satu sebab yang ditinggalkan tatkala orang Tionghoa sudah beralih menjadi Muslim adalah penghilangan identitas ketionghoaannya. ${ }^{19}$ Anggapan ini meskipun menggembirakan, namun juga menyisakan kekhawatiran, khususnya mengenai kelangsungan Tionghoa sebagai suatu sistem budaya. Memang, kepercayaan tradisional berkaitan erat dengan pernak-pernik keseharian orang Tionghoa. Bisa dilihat di toko-toko milik orang Tionghoa, yang memasang altar kecil persembahan bagi leluhur atau dewa yang disembahnya. Melepaskan diri dari agama Tonghoa, sama halnya dengan meninggalkan kepecayaan yang diwariskan oleh leluhur. Sedangkan belum ada semacam produk-produk kebudayaan yang konsisten mengawinkan wawasan ketionghoaan-keindonesiaan-keislaman. Jikapun

\footnotetext{
${ }^{17}$ Wawancara dengan Marsudi (Yo Bun Siong) di Desa Kohod pada 11 Juni 2016.

${ }^{18}$ Leo Suryadinata, Negara dan Etnis Tionghoa Kasus indonesia (Jakarta: LP3ES, 2002) hlm.

${ }^{19}$ Leo Suryadinata, Negara dan Etnis ..., hlm. 54.
} 53.

42 | TamaddunVol. 7 , No. I, Januari - Juni 2019 
ada maka belumlah menjadi suatu identitas yang mengakar. Sebagian orang Cina Benteng meyakini bahwa Islam hanyalah tradisi masyarakat pribumi. Semua agama pada hakekatnya mengajarkan kebaikan. Berbeda agama bukan berarti halangan untuk bermasyarakat. Kedudukan Islam sama dengan ajaran Tao yang diajarkan oleh leluhur. Islam telah menjadi tradisi orang Tangerang pribumi. ${ }^{20}$ Keyakinan atau kepercayaan orang Tionghoa yang menyelipkan kepercayaan dunia adi kodrati dengan tradisi asal, mempertegas pandangan bahwa kepercayaan tidak bisa dilepaskan dari asal-muasal agama itu lahir dan berkembang. Agama memiliki karakteristik yang berasal dari tempat kelahirannya. Tata cara ritual agama bersifat natural dan dekat dengan kondisi latar kehidupan para penganutnya. ${ }^{21}$

Agama adalah sesuatu yang sangat sosial. Kendatipun sebagai individu yang memiliki pilihan-pilihan dalam hidup ini, namun pilihan-pilihan itu tetap dalam kerangka sosial. Faktanya manusia adalah mahluk sosial. Sejak kelahirannya manusia lahir dalam sebuah kelompok. Berbicara bukan dengan bahasa yang kita buat sendiri, menggunakan perkakas bukan yang dibuatnya sendiri, ilmu pengetahuan yang dimiliki bukan dari hasil penggalian sendiri. Dalam setiap kebudayaan, agama adalah bagian yang paling berharga dari seluruh kehidupan sosial. Agama melayanai anggota masyarakat dengan menyediakan ide, ritual-ritual dan perasaan-perasaan yang akan menuntun seseorang dalam hidup bermasyarakat.

Jika diperhatikan, masyarakat Cina Benteng adalah buah dari proses dialogis kehadiran mereka di Tangerang sejak masa yang lama. Kepercayaan pada leluhur yang mendarah daging serta ritual keagamaan yang bersifat warisan yang harus terus dilakukan merupakan bukti kesinambungan masa lalu dengan masa kini serta masa depan. Denyut kepercayaan Tionghoa akan tetap semarak manakala anggota etnisnya tetap melestarikan peninggalan leluhur. Sama seperti suku-suku

${ }^{20}$ Wawancara dengan Salim (Lim Han Liong) Pengurus Klenteng Lun Shan Bio, Kedaung, Tangerang pada 11 Juni 2016.

${ }^{21}$ Emile Durkheim, The Elementary Forms of The Religious Life, Terj. Joseph Ward Swain (New York: Dover Publication, Inc, 2008)hlm. 24.

43 | TamaddunVol. 7 , No. I, Januari - Juni 2019 
lain yang masih mempraktekkan adat istiadat lokal, begitu pula orang Tionghoa yang memiliki adat istiadat tersendiri. Meskipun ritual kepercayaan yang mereka lakukan tidaklah selalu sama dengan yang ditemui di Republik Rakyat Tiongkok masa kini, paling tidak mereka masih merasa mengerjakan apa yang menjadi wasiat nenek moyang.

Ritual-ritual keagamaan, lebih utama dan lebih fundamental sehingga melahirkan keyakinan. Jika memang ada sesuatu yang paling abadi dalam agama, maka kebutuhan masyarakat akan ritual-ritual itulah yang paling abadi, yang berupa upacara-upacara peneguhan kembali dedikasi setiap anggota masyarakat. Dengan ritual-ritual tersebut seluruh anggota masyarakat diingatkan kembali bahwa kepentingan bersama lebih utama dibandingkan kepentingan pribadi. Sebaliknya, keyakinan bukanlah hal yang paling abadi karena fungsi-fungsi sosial dari ritual keagamaan akan selalu konstan, sebaliknya muatan intelektual agama akan selalu mengalami perubahan. Perbedaan ide-ide dalam agama yang ada di dunia akan selalu dijumpai bahkan ide-ide dalam satu agama juga kadang-kadang berbeda namun kebutuhan akan ritual-ritual akan selalu ada. Ritual dan upacara merupakan sumber dari kesatuan sosial, pengikat utama seluruh anggota masyarakat. Ritualritual itu akhirnya akan dapat mengungkap arti agama sesungguhnya.

Agama sangat dekat dengan aspek supernatural ${ }^{22}$, begitu pula yang ditemui dalam kepercayaan Tionghoa. Hal ini bisa dilihat dari kepercayaan mereka tentang memulyakan orang tua. Meskipun para leluhur sudah meninggal, mereka tetap bersembahyang atas namanya. Orang Cina Benteng masih melestarikan tradisi ini. Di pemukiman Orang Cina Benteng di bantaran Kali Cisadane terdapat beberapa klenteng dan rumah warga yang di dalamnya menyimpan persembahan untuk para leluhur mereka. Bisa dikatakan ini merupakan wujud ritual agama orang Tionghoa yang asli dan telah menjadi identitas dari sistem kepercayaan mereka.

\footnotetext{
${ }^{22}$ Emile Durkheim, The Elementary Forms ..., hlm. 24.
} 
Biasanya, pemujaan terhadap leluhur juga dibuktikan dengan menyimpan abu dalam rumah, dan ayah sebagai kepala keluarga yang memimpin upacara. Kewajiban ini diturunkan kepada anak lelaki sulung dan begitu selanjutnya. Anak perempuan yang telah menikah akan ikut dengan suaminya, dan ia akan memuja leluhur pihak suaminya. Ada semacam pemahaman bahwa anak lelaki adalah penting keberadaannya, karena ia akan melanjutkan tradisi hao (bakti) leluhurnya. Kebutuhan anak laki-laki bukan hanya sekedar pelanjut she-nya (nama keluarga), namun juga untuk menggantikan tugas ayahnya sebagai perawat abu leluhurnya. ${ }^{23}$ Dalam ajaran Kong Fu Tse, dikatakan bahwa merupakan suatu ketidakbaktian (put hao), jika melakukan tiga hal, yang salah satunya adalah tidak mempunyai anak. ${ }^{24}$

Orang Tionghoa menganggap bahwa keberadaan mahluk mustahil terjadi tanpa melalui peran orang tua yaitu melaui proses evolusi biologis. Berbeda dengan Islam yang percaya bahwa zat Yang Maha Pencipta dapat melakukan apa saja termasuk penciptaan manusia melalui proses yang dikehendakiNya, melalui peran orang tua ataupun tidak. Tuhan dipercaya pernah menciptakan Isa tanpa peran seorang ayah. Tuhan juga digambarkan telah menciptaka Adam tanpa peran orang tua sama sekali baik ayah ataupun ibu.

Arti penting ritual keagamaan pada gilirannya akan membawa kita pada inti dari teori Durkheim, yaitu penjelasan fungsional tentang agama. Dalam pendekatan intelektualis, keyakinan dan ide-ide yang disebut Durkheim sebagai sisi spekulatif agama adalah kata kunci untuk menjelaskan kebudayaan. Sebagai contoh, bagaimana memahamisimbol-simbol dalam upacara-upacara kematian orang Tionghoa. Ada replica dari benda-benda kesayangan milik "si mati" semasa hidupnya yang dibakar. Begitu juga dengan uang-uang kertas yang dibakar. Walaupun banyak kalangan mereka sendiri menganggap hal seperti itu adalah

\footnotetext{
${ }^{23}$ Lebba Kadorre Pongsibanne, Islam dan Budaya Lokal (Ciputat: Mazhab Ciputat, 2013) hlm. 210.

${ }^{24}$ Lebba Kadorre, Islam dan Budaya ..., hlm. 210.
}

45 | TamaddunVol. 7 , No. I, Januari - Juni 2019 
absurd, bahkan mereka sendiri menyebutnya sebagai Hell's Money, atau uang neraka. Jika hal-hal tersebut dianggap absurd, lalu mengapa ritual-ritual itu tetap dipertahankan dalam rentang waktu yang demikian panjang ?

Jawaban dari pertanyaan itu hanya bisa ditemukan pada satu titik, yaitu pada fungsi sosialnya, bukan pada muatan-muatan keimanan atau apa yang mereka yakini. Arti penting agama justru terletak pada ritual-ritual yang dapat memberikan semangat kepada individu-individu kelompok mereka. Ritual dan upacara juga berfungsi sebagai pengikat yang dapat mempererat hubungan antar individu tersebut. Pada akhirnya ritual dan upacara tersebut kemudian menciptakan kebutuhan akan adanya satu simbol yang menggambarkan ide-ide dan keyakinan tentang roh-roh leluhur dan dewa-dewa. Walaupun ide-ide agama dianggap absurd dan salah oleh beberapa kalangan namun perilaku keagamaan akan tetap selalu ada dalam setiap masyarakat, karena perilaku keagamaan berupa ritual maupun upacara dianggap memberikan kekuatan pada masyarakat. Ide-ide dan keyakinan bisa diperdebatkan, tapi ritual-ritual atau bentuk-bentuk lainnya yang sama fungsinya akan tetap dipertahankan. Masyarakat tidak akan eksis tanpa adanya upacaraupacara karena dengan begitu agama akan tetap selalu ada.

Islam merupakan alat asimilasi yang pernah didengungkan sebagai cara alternatif mengatasi problem ketionghoaan. Namun, ketika melihat kasus Cina Benteng, Islam tidak bisa dikatakan hanya alat tunggal dalam hal tersebut. Lingkungan budaya serta bahasa yang justru menjadi alat asimilasi yang lebih dominan. Mereka masih tetap menjalankan beberapa ritual dan kepercayaan leluhur, meskipun bentuknya berlainan dengan yang ditemukan di Tiongkok Daratan.Sebagai contoh, mereka tetap memulyakan leluhur dengan cara memujanya. Ini seperti kompromi dari upaya resistensi mereka akan tradisi leluhur di tengah lingkungan yang berbeda, yang perlahan membentuk kepribadian berbudaya yang sama dengan suku bangsa lainnya. 


\section{Faktor Penghambat Berkembangnya Islam di kalangan Cina Benteng}

Merupakan pandangan yang bisa dimaklumi,jika disebutkan Islam merupakan agama minoritas bagi masyarakat Cina Benteng. Apalagi di antara orang Tionghoa Keturunan, dalam sejarahnya banyak yang memilih menjadi warga pribumi dengan meninggalkan adat istiadat serta budaya yang menjadi identitas Tionghoa. Akan muncul dua sudut pandang antara Cina Benteng yang Muslim yang masih melakukan tradisi ketionghoaan dan Cina Benteng Muslim yang berasimilasi dengan penduduk pribumi, sehingga mereka hampir tidak bisa lagi dikatakan sebagai Tionghoa Keturunan. Terlepas dari itu, setidaknya kini masih dapat dijumpai orang Cina Benteng yang Muslim meskipun terbatas.

Penulis tidaklah ingin menghubungkan wacana kesejarahan dengan sesuatu yang bersifat kuantitas. Memang, bisa dikatakan besarnya peradaban Islam akan berdampak signifikan bagi jumlah umat Islam yang jumlahnya banyak. Terlebih wacana Islam sudah menjadi doktrin dalam keluarga, budaya dan lingkungan sosial. Dalam kasus Cina Benteng, anggapan mengenai sejarah dan kuantitas semacam itu sudah selaiknya dipinggirkan. Karena, peneliti ingin mengangkat sejarah Islam dalam masyarakat Cina Benteng hanya sebagai suatu ingatan historis atau bahan telaah bahwa sejatinya Islam pernah pula beredar di kalangan leluhur mereka, meskipun relevansi kontinuitasnya pada masa kini belum terlalu kelihatan.

Keinginan orang memeluk Islam seyogyanya tidak berhenti pada masalah hidayah. Petunjuk dari Tuhan merupakan lahan lain yang sifatnya transendental, tidak bisa diungkap secara ilmiah. Jikapun bisa maka sifatnya terlalu subjektif. Ketertarikan orang akan suatu agama juga bisa dilihat dari kondisi sosial, yakni menyangkut pergaulannya dengan orang di sekitarnya. begitu pula sebaliknya, ada faktor sosial lainnya yang menyebabkan seseorang justru enggan masuk dalam suatu agama tertentu. Alasan terkuat salah satunya adalah menyangkut latar belakang budaya yang dimilikinya. 
Terdapat beberapa alasan yang melatarbelakangi mengapa perkembangan Islam terhambat dalam tubuh masyarakat Cina Benteng, antara lain sebagai berikut:

Pertama, budaya judi dan makan daging babi yang telah mendarah daging di tengah kehidupan orang Tionghoa. Judi merupakan salah satu kebiasaan orang Tionghoa yang sudah mengakar, termasuk juga makan daging babi. Bagi mereka keduanya lebih dari pada sekedar aktivitas harian, melainkan sudah menjadi tradisi yang perlahan menyokong identitas ketionghoaan mereka. Dua hal ini merupakan larangan dalam ajaran Islam. Jika sudah menjadi Muslim, maka tidak diperkenankan untuk melakukan dua kegiatan itu. Bagi orang Tionghoa, meninggalkan keduanya adalah berat, sama halnya dengan memutuskan diri dari jalinan budaya nenek moyang.

Di Museum Benteng Heritage yang terletak di Kota Tangerang, terdapat meja judi orang Tionghoa tempo dulu yang bentuknya unik. Meja ini dibentuk sedemikian rupa, untuk mengakomodiraktifitas berjudi. Meja itu dilengkapi dengan laci tempat uang serta tempat makan bagi masing-masing pelakunya. Penyediaan fasilitas tempat makanan menggambarkan bahwa aktifitas judi bagi orang Tionghoa bisa berlangsung dalam tempo yang panjang sehingga dianggap perlu untuk menyediakan tempat makanan agar pelakunya tak perlu harus meninggalkan arena hanya karena rasa lapar. Peninggalan ini sekaligus menjadi penguat anggapan bahwa budaya judi begitu lekat dengan orang Cina Benteng.Berjudi merupakan wahana yang tepat dalam memupuk semangat kolektivitas. Terkadang jumlah yang dipertaruhkan tidaklah menjadi soal, asalkan mereka bisa berkumpul dengan teman sebangsanya. Jika mengalami kekalahan dalam berjudi, mereka menganggapnya sebagai buang sial.

Kedua, Materialisme. Ideologi ini begitu kuat mengakar dalam masyarakat Tionghoa. Secara umum begitulah anggapan awam terhadap masyarakat etnis ini. Etos kerja yang tinggi yang seharusnya mendapat apresiasi justru menjadi 
cemoohan dari beberapa kalangan. Para Kyai menyebutnya dengan "kedunyan" yang berarti orang yang terlalu mengutamakan kehidupan duniawi.Materialisme orang Tionghoa tidak saja terbatas pada kehidupannya, bahkan hingga kematiannya.Runtutan ritual kematian merupakan salah satu episode kehidupan paling penting bagi orang Tionghoa. Kematian tidak selesai jika hanya didoakan lantas dikremasi begitu saja. Mereka yang berasal dari kelompok berpunya, akan menjadikan kematian ini sebagai perayaan serta unjuk kekayaan yang disokong oleh megahnya pesta kematian serta jumlah massa yang datang berduyun-duyun. Upacara kematian orang Tionghoa kerap diselenggarakan hampir menyerupai suatu parade budaya yang sekaligus menampilkan kebesaran orang yang mati serta keluarga yang menyertainya.

Dalam prosesi penguburan jenazah, biasanya ikut dikuburkan pula barangbarang kesayangan si mati di masa-masa yang lalu.Barang kesayangan ini disertakan dalam liang pekuburan. Misalnya ia mencintai perhiasan serta uangnya, maka barang-barang itu akan dikuburkan di sisinya. Kepercayaan ini dilakukan agar si jenazah dapat tenang di alam kemudian. Benda-benda kesayangannya akan digunakan sebagai modal di sana. Orang Tionghoa percaya uang, perhiasan atau emas itu akan digunakan oleh roh orang yang mati sebagai bekal hidup di alam kelanggengan, sama seperti bekal kubur pada masyarakat sejak masa pra sejarah.

Lambat laun, penggunaan barang-barang asli sebagai bekal kubur mulai ditinggalkan. Sebagai gantinya, mereka membuat miniatur replika barang-barang tersebut, misalnya replika pesawat, mobil, emas-emasan, bahkan uang pun yang nantinya menjadi bekal adalah uang palsu atau dalam istilah mereka disebut "uang neraka". Tidak jelas memang mengapa uang itu dinamakan demikian, namun yang jelas terjadi semacam perubahan persepsi mengenai barang-barang demikian, yang disandarkan pada pemikiran materialistis-pragmatis. Jika barang-barang palsu tersebut diyakini bisa menjadi bekal, maka mengapa harus menyertakan barang 
yang asli? Yang masih mempunyai nilai ekonomi yang tinggi dan dapat dipergunakan oleh keluarganya yang masih hidup, demikian hemat mereka.

Onghokham menyebutkan bahwa label Orang Tionghoa yang dikatakan sebagai "manusia ekonomi”, sesungguhnya adalah bentukan zaman. Sejak masa kolonial hingga Orde Baru, orang Tionghoa mengalami peminggiran hak-hak bernegara, berbudaya dan berpolitik dan satu-satunya peluang yang dimiliki mereka adalah bergerak di sektor ekonomi. Sejak masa kolonial, orang Tionghoa yang kaya sudah terbiasa menyelenggarakan upacara pemakaman yang monumental, seperti pemakaman Mayor Tan Tjien Kie, Mayor Cina Cirebon, Opsir Cina yang terkaya sepanjang abad 19. Biaya pemakamannya menyentuh angka 100.000 gulden. Mereka yang sudah meninggal disemayamkan di musoleum yang indah dan megah sebagaimana bisa dijumpai di pemakaman Karet Jakarta. Belum lagi yang hidup diharuskan membangun meja sembahyang untuk pemujaan nenek moyang yang menelan biaya yang tidak sedikit. ${ }^{25}$

Sepertinya, kemegahan penguburan orang Tionghoa telah menjadi tradisi yang akarnya bisa ditemukan sejak masa prasejarah. Tonkin, disebut-sebut merupakan tempat asal migrasi produk-produk kebudayaan ke kawasan Nusantara. Daerah tersebut adalah pusat kebudayaan perunggu di Asia Tenggara. Di Dongson, juga ditemukan kepingan uang zaman Dinasti Han (Sekitar 100 tahun SM) dan nekara kecil sebagai bekal orang mati. ${ }^{26}$ Sejak masa yang lama kebudayaan orang Tiongkok telah sampai ke Indonesia. Hal ini bisa dijadikan alasan mengapa hingga kini orang Tionghoa masih menyertakan benda-benda yang dianggap mewakili kekayaan semasa hidup sebagai bekal kubur.

Dalam Islam dikenal kesamaan tindakan dalam memperlakukan orang mati. Baik miskin ataupun kaya, berpangkat atau tidak, maka tetap saja mereka akan

\footnotetext{
${ }^{25}$ Onghokham, Anti Cina ..., hlm. 44.

${ }^{26}$ Sidi Ibrahim Boechari, Prasejarah Indonesia (Jakarta: Gunung Tiga, 1985) hlm. 81-82.
}

50 | TamaddunVol. 7 , No. I, Januari - Juni 2019 
disucikan, dikafani, dishalati lantas dimakamkan. ${ }^{27}$ Secara umum hampir tidak ada perbedaan yang mencolok dari prosesi kematian semua orang Muslim di Indonesia. Jika diperhatikan ajaran Islam lebih menempatkan prosesi kubur sebagai bentuk bersahaja dari pengamalan ketentuan Islam. Simbol-simbol yang terlihat berupa penggunaan kain putih sebagai pembungkus mayat, penguburan di tanah merah dan setiap prosesi diiringi dengan shalawat dan doa adalah rangkaian kegiatan yang jauh dari sifat materialistis. Amat berbeda dengan ajaran Orang Tionghoa.

Dalam kehidupan Muslim, kematian dianggap sebagai suatu fenomena yang pasti akan dialami setiap manusia. Tidur, dalam ajaran Islam sudah dianggap sebagai keadaan tubuh "mati sementara" yang tercermin dalam doa bangun tidur: "Segala puji bagi-Mu ya Allah, yang telah menghidupkan kembali diriku setelah kematianku, dan hanya kepada-Mu nantinya kami semua akan berpulang kepada$\mathrm{Mu}$. Oleh orang Jawa, hidup diartikan sebagai "hanya mampir minum", yang mengindikasikan bahwa dunia kematian adalah justru kehidupan yang sebenarnya. Setiap warna kehidupan sudah seharusnya diterima secara lapang dada dan disyukuri. Pada titik ini ada korelasi antara pandangan hidup orang Jawa dan ajaran Islam yang bermuara pada kepasrahan dan kebersahajaan. ${ }^{28}$

Bagi orang Tionghoa yang masih memegang teguh adat nenek moyang serta kebesaran nama keluarga, penguburan model Islam tentu menjadi hal yang tidak terpikirkan. Mengantar orang yang mati dengan kebesaran adalah suatu tugas mulia, sebagai bentuk penghormatan terakhir baginya. Model penguburan orang Islam yang penuh kesahajaan dianggap bukan meruapakan bukti penghormatan yang seharusnya dan bukan merupakan ajaran Tionghoa yang otentik. Untuk itu

${ }^{27}$ Lebih lanjut mengenai tata cara memperlakukan mayat menurut hukum Islam lihat Syekh Zainuddin bin Abdul Aziz al-Malibari, Fathul Mu'in Jilid 1, Terj. Aliy As'ad (Kudus: Menara Kudus, 1980) hlm. 354-366.

${ }^{28}$ Abdul Karim, "Makna Kematian dalam Perspektif Tasawuf” dalam Esoterik, Vol. I, No. 1, Juni 2015, hlm. 23-26. 
alasan ini kiranya juga menjadi latarbelakang mengapa orang Tionghoa, terutama yang kaya, enggan memeluk Islam.

Ketiga, orang Tionghoa akan mempertimbangkan agama Budhha ketimbang Islam. Secara kultural, ajaran Buddha lebih dekat dengan tradisi Tionghoa. Sama seperti Islam, ajaran ini juga mengedepankan kepasrahan dan kebersahajaan bagi penganutnya. Bahkan dalam beberapa segi, ajaran Buddha lebih radikal dalam mendudukkan makna kesederhanaan. Sama seperti Konghuchu, Budha merupakan kepercayaan yang banyak dipeluk orang Tionghoa. Bahkan pada satu fase, kepercayaan ini sempat mengalami fusi ke dalam aliran Tri Dharma, bersama pengikut ajaran Tao dan Konfusius.

Jika dilihat arsitektur vihara pengikut Tri Dharma bentuknya unik. Bangunannya begitu didominasi oleh unsur-unsur budaya Tionghoa, seperti cat berwarna merah, patung naga liong dan lain sebagainya. Namun yang menjadi fokus keunikan, adalah ketika memasuki ruang sembahyang utama, di meja altar terdapat tiga patung persembahan yang diletakkan sejajar. Ketiga patung itu adalah Buddha Gautama, Lao Tse dan Konfusius. Vihara ini menjadi titik berkumpul penganut tiga aliran ini. Sisi positif yang bisa dilihat dari keberadaan Tri Dharma adalah menciptakan persatuan Tionghoa.

Meskipun tata cara peribadatan Buddha lebih sederhana, namun ajaran ini termasuk banyak dianut oleh orang Tionghoa. Kebersahajaan yang ditampilkan mampu memikat orang-orang yang mendambakan kesederhanaan dan berusaha positif dalam kehidupan. Di tambah lagi, aliran Budha termasuk kepercayaan yang sudah berkembang pesat di Tiongkok Daratan. ${ }^{29}$ Tionghoa penganut Buddha tentu

${ }^{29}$ Ajaran Buddha datang dari India ke Tiongkok sekitar 2000 tahun yang lalu. Ajaran Buddha di sini dikasifikasikan ke dalam tiga komunitas berdasarkan tiga bahasa yang digunakan, yakni Mandarin, Tibet dan Bali. Kelompok Buddha Mandarin berasal dari suku Han Tiongkok, aliran Buddha Tibet (disebut juga Lamaist) adalah orang-orang dari bangsa Tibet, Mongolia, Uyghur,

52 | TamaddunVol. 7 , No. I, Januari - Juni 2019 
merasa mereka masihlah berada dalam koridor tradisi nenek moyang, dan tidak tercerabut jauh dari para kerabatnya yang menganut kepercayaan penyembahan dewa-dewa yang amat banyak itu. Bikkhu Sujato menjelaskan bahwa dalam perspektif Budhis, kehidupan manusia layaknya api. Di dalam kehidupan berisi segala bentuk problematika hidup. Seseorang yang ingin mencapai nirwana,maka harus "keluar dari nyala api". Proses berada di alam api adalah sebagian dari proses spiritual yang harus dilalui dan masanya adalah panjang tidak bisa hanya seketika (sebentar). Kalimat "keluar dari api" terjadi secara alami,yakni setelah manusia merasakan api itu sendiri. dengan kata lain "keluar dari api" adalah hasil dari pencapain spiritual yang hampir selesai. ${ }^{30}$

Keempat, Islam adalah agama yang dianut oleh mayoritas pribumi, Islam adalah representasi dari pribumi yang identik dengan kurang berpendidikan, miskin, primitif dan barbar. Kristen menjadi pilihan yang dianggap lebih realistis bagi orang Cina benteng yang ingin melakukan konversi agama. Pada masa kolonial, masuk ke dalam Kristen dapat menyejajarkan diri dengan orang-orang Eropa. Sebagaimana kita ketahui bahwa pada masa kolonial, masyarakat dibagi menjadi tiga golongan, yang paling atas adalah golongan Eropa, yang kedua adalah golongan Asia (Jepang dan Tiongkok) dan Timur asing (Arab). Yang paling bawah adalah Pribumi, bangsa terjajah.

Dengan memeluk Kristen, mereka dapat beribadah bersama orang-orang eropa, dapat mengenakan busana eropa, mengikuti pesta dansa yang sering kali diadakan orang-orang eropa, Menggunakan nama-nama eropa di depan nama keluarga mereka, dan pada gilirannya dapat menjalin hubungan bisnis dengan

Lhoba, Moinba dan Tujia. Sedangkan ajaran Buddha berbahasa Bali dianut oleh etnis Dai dan Bulang yang mendiami Provinsi Yunan. Lihat "Mengenal Agama dan Kepercayaan di Tiongkok" diunduh dari http://yinhuadaily.com/mengenal-agama-dan-kepercayaan-di-tiongkok/ pada hari Jumat, tanggal 17 Juni 2016, pukul 09.40 WIB.

${ }^{30}$ Bikkhu Sujato, Kelahiran Kembali dan Keadaan Antara dalam Buddhisme Awal, Terj. Ariyakumara (t. Tp: Dhammacitta Press, 2008) hlm. 20-21; artikel ini bisa diunduh di http://dhammacitta.org pada hari Selasa, tanggal 14 Juni 2016, pukul 08. 30 WIB. 
orang-orang eropa yang biasanya mereka terdiri dari aparat penguasa kolonial dan pengusaha besar yang biasanya menguasai perkebunan besar yang tentu saja mereka membutuhkan sarana distribusi bagi hasil perkebunan mereka. Anggapan itu tidak begitu saja bisa terhapus hingga sekarang.

Kelima, Islam identik dengan kengerian. Islam dianggap agama yang mengajarkan tentang hal-hal yang menakutkan yang tidak diajarkan agama-agama lain di muka bumi ini. Hal-hal mengenai siksa kubur, siksa neraka yang digambarkan begitu menyeramkan menjadi sesuatu yang tidak ingin mereka memikirkannya, apalagi mengalaminya. Radikalisme yang ditanamkan beberapa aliran Islam juga ikut mempengaruhi citra Islam di kalangan masyarakat Tionghoa.

Kelima faktor di atas merupakan sebagian dari alasan mengapa Orang Tionghoa tidak mau menjadi Muslim. Meskipun faktor-faktor itu bisa jadi berbeda dengan apa yang dilihat orang lain, setidaknya peneliti telah menemukan beberapa alasan di balik sedikitnya jumlah orang Tionghoa Muslim. Islam bagi masyarakat Cina Benteng memang menjadi suatu ingatan historis keberadaan mereka. Mereka tidak menampik bahwa leluhur mereka ada yang berasal dari kalangan Tionghoa Muslim. Bagi Tionghoa peranakan, Ibu mereka juga orang pribumi yang dapat dipastikan Muslim. Namun, pada perkembangannya Islam tidak menjadi agama mayoritas yang dipeluk oleh Tionghoa. Ini merupakan suatu kasus unik dalam kajian sejarah Indonesia, di mana Islam justru surut dalam perkembangannya.

\section{Konversi agama pada masyarakat Cina Benteng}

Konversi agama pada Masyarakat Cina Benteng terjadi dalam beberapa fase dari Masa awal terbentuknya masyarakat Cina Benteng, Masa Kolonial, masa orde 
baru hingga sekarang. Konversi agama yang dimaksudkan penulis adalah konversi agama yang bersifat massif.

Pertama, yaitu pada masa awal. Sebagaimana dijelaskan di depan bahwa masyararakat awal Cina Benteng adalah mereka yang mendarat di Teluk Naga yang dipimpin oleh Chen Tji Lung. Sebagai pengikut Laksamana Cheng Ho, tentu banyak dari mereka yang menganut Islam karena Laksamana Cheng Ho sendiri adalah seorang Muslim yang juga mempunyai nama yaitu Ma He. Ma adalah singkatan bagi Muhammad, jadi artinya adalah Muhammad He. ${ }^{31}$

Ternyata banyak dari pengikut Cheng Ho adalah orang-orang taklukan. Mereka adalah para perompak yang dikalahkan Cheng Ho di Malaka, Bintan dan Palembang. ${ }^{32}$ Sebagai orang-orang taklukan mereka mengikuti Cheng Ho dan akhirnya menganut Islam sebagaimana agama yang dianut Laksamana Cheng Ho. Setelah mereka menetap di Tangerang dan misi muhibah Laksamana Cheng Ho kembali ke Tiongkok, Orang-orang taklukan ini mulai banyak yang kembali kepada agama leluhur. Seperti yang terjadi di Semarang, Masjid yang dibangun berubah menjadi kelenteng Sam Po Kong. ${ }^{33}$

Kedua, pasca peristiwa 1740 di Batavia, Banyak orang-orang Tionghoa Batavia yang mengungsi ke wilayah Tangerang dan menemukan saudara satu leluhur mereka. Para pendatang dari Batavia itu sering kali melakukan ritual-ritual upacara yang menghidupkan kembali budaya dan tradisi Tionghoa. Orang-orang Cina Benteng yang banyak memeluk Islam karena menikah dengan perempuan pribumi (Islam) kembali kepada agama leluhur mereka yaitu Konfusianisme, Taoisme dan Budhisme.

\footnotetext{
${ }^{31}$ Wawancara dengan Udaya Halim.

${ }^{32}$ MO Parlindungan, Tuanku Rao, (Yogyakarta : LKiS, 2007) hlm. 652.

${ }^{33}$ Slamet Muljana, Runtuhnya Kerajaan Hindu-Jawa dan Timbulnya Negara-Negara Islam di Nusantara (Yogyakarta: LKiS, 2009), hlm. 193.
}

55 | TamaddunVol. 7 , No. I, Januari - Juni 2019 
Ketiga, Pada masa kolonial banyak orang-orang Tionghoa yang mengubah keyakinan agamanya kepada Kristen. Hal tersebut terjadi lebih disebabkan faktor sosial dan ekonomi. Seperti telah dijelaskan di muka bahwa pada masa kolonial, Belanda menggolongkan masyarakat menjadi tiga strata, yang teratas adalah golongan Eropa. Bagian ini diisi oleh orang-orang Belanda baik sebagai aparat pemerintahan kolonial maupun para pengusaha. Selain orang Belanda ada juga pengusaha dari Inggris. Sebagaimana diketahui bahwa Inggris juga sempat menguasai atau menjajah di Nusantara. Demikian pula dengan orang-orang dari Perancis. Golongan dibawahnya adalah golongan Asia dan Timur Asing, yaitu orang-orang Tionghoa, Jepang, India dan Timur Tengah. Biasanya mereka adalah para saudagar. Pada strata masyarakat yang paling rendah didisi oleh pribumi yang mempunyai konotasi tak berpendidikan dan miskin. Tentunya banyak orang Tionghoa yang ingin naik kelas, stidaknya bisa dekat dan akrab dengan orangorang Eropa yang berkonotasi lebih berpendidikan dan seabagai penguasa kolonial. Jika mereka masuk ke dalam Kristen mereka dapat beribadah bersama-sama dengan orang Eropa, bergaul dengan mereka dan berpenampilan seperti orang Eropa serta berpeluang mendapatkan fasilitas untuk digunakan mengambil keuntungan ekonomi.

Seperti yang diungkapkan Karl Marx, bahwa agama sama saja dengan negara, seni, tatanan moral,dan hasil karya intelektual lain. Semua itu merupakan superstruktur masyarakat yang sangat tergantung pada pondasi ekonomi. Maka, seandainya terjadi perubahan ekonomi, agamapun akan ikut berubah. ${ }^{34}$

Keempat adalah pada masa Orde Baru. Pemerintahan orde Baru hanya mengakui empat agama yaitu Islam, Kristen dimana Protestan dan Katolik ada di dalamnya, Hindu dan Budha. Pada masa pemerintahan Orde Baru, Orang orang Tionghoa mengalami diskriminasi dimana agama mereka, yaitu Konghucu dan

\footnotetext{
${ }^{34}$ Palls, Seven Theories..., hlm 213.
} 
Taoisme tidak diakui oleh negara. Agar mendapat pengakuan secara administratif dari negara, kebanyakan dari mereka mengubah keyakinan mereka menjadi Budha. Budha adalah ajaran agama yang paling dekat dengan kosmologi orang Cina Benteng. Banyak juga dari mereka menganut Budha sejak nenek moyang mereka. Kelenteng-kelenteng mereka diubah namanya menjadi vihara agar dari luar mereka dianggap Budha walaupun setelah masuk ke dalam kelenteng, mereka beribadat menurut ajaran Konfusius. Di Desa Tanjung burung peneliti menemukan sebuah vihara yaitu Vihara Atta Naga Vimutti. Dari namanya, terkesan bahwa vihara ini adalah tempat ibadah bagi umat Budha. Pada kenyataannya didalam Vihara ini memang terdapat altar Budha tetapi di sebelahnya juga terdapat altar pemujaan Dewi Kwan Im yaitu Dewi Welas Asih yang banyak dipuja oleh umat Konghucu.

Budha adalah agama yang merupakan paling banyak dipilih oleh kalangan masyarakat Cina Benteng. Pilihan terhadap Budha tentunya di latarbelakangi oleh sejarah agama Budha di Tiongkok yang juga mendapatkan sambutan yang luas. Pada urutan berikutnya adalah masuk Kristen, baik Protestan maupun Katolik. Pilihan ini juga didasarkan pada alasan-alasan sosial ekonomi, sama seperti yang terjadi pada masa kolonial. Pilihan masuk Islam adalah urutan berikutnya. Biasanya motivasinya adalah kedekatan hubungan personal dengan guru-guru spiritual. Motivasi yang terbanyak adalah perkawinan dengan perempuan pribumi.

\section{Kesimpulan}

Sebagai sebuah budaya, Islam dapat diterima dengan baik oleh seluruh masyarakat, tak terkecuali masyarakat Cina Benteng. Nilai-nilai rahmatan lil alamin ternyata dapat dengan jelas dirasakan oleh mereka. Tradisi dan kebudayaan pribumi yang notabene Islam juga dapat diterima dan diakomodir dalam keseharian mereka. Menggunakan sarung dan peci bukanlah hal yang aneh bagi orang Cina Benteng. Dalam hal berkesenian, kolaborasi antara permainan alat-alat musik khas 
Tiongkok dengan permainan alat musik lokal menjadi simbol dapat diterimanya budaya dan tradisi Islam oleh masyarakat Cina Benteng.

Penerimaan Budaya dan tradisi Islam oleh kalangan orang Cina Benteng tidak berbanding lurus dengan Islam sebagai agama dan doktrin. Kewajiban menjalankan rukun Islam bagi setiap pribadi muslim ini dirasa sangat memberatkan mereka. Larangan terhadap aktifitas judi, makan babi dan minum arak juga dianggap terlalu berat karena kegiatan itu sudah mendarah daging menjadi tradisi turun temurun. Doktrin tentang dosa, siksa kubur dan siksa neraka dirasa sangat menakutkan. Kesan tidak modern juga terlanjur melekat pada masyarakat pribumi yang kebetulan muslim. Terlalu banyak hal yang harus dirubah jika seorang Tionghoa mau masuk ke dalam Islam. 


\section{Daftar Pustaka}

Abdurrahman, Dudung,Metode Penelitian Sejarah (Tangerang: Logos Wacana Ilmu, 1999).

Boechari,Sidi, Ibrahim,Prasejarah Indonesia (Jakarta: Gunung Tiga, 1985).

Creel, H.G., Alam Pikiran Cina; Sejak Confusius sampai Mao Zedong, Terj. Soejono Soemargono (Yogyakarta: Tiara Wacana, 1990).

De Graaf,H. J. dkk, Cina Muslim di Jawa Abad XV dan XVI antara Historisitas dan Mitos (Yogyakarta: Tiara Wacana, 1998).

Durkheim,Emile, The Elementary Forms of The Religious Life, Terj. Joseph Ward Swain (New York: Dover Publication, Inc, 2008).

Gutzlaff,K., Aan mijne mede-christenen in Nederland (Amterdam: Loman Jr, $1850)$.

Jahja Junus, Peranakan Idealis; Dari Lie Eng Hok dampai Teguh Karya (Jakarta: Kepustakaan Populer Gramedia, 2003).

Karim, Abdul, "Makna Kematian dalam Perspektif Tasawuf" dalam Esoterik, Vol. I, No. 1, Juni 2015.

Kuntowijoyo, Pengantar Ilmu Sejarah (Yogyakarta: Bentang, 1995).

Madjid, M. Dien, dan Wahyudhi, Johan, Ilmu Sejarah Sebuah Pengantar (Jakarta: Kencana, 2014).

Mashad, Dhurorudin, Muslim di Cina (Jakarta: Pensil 324, 2006).

Mulyana, Slamet, Runtuhnya Kerajaan Hindu-Jawa dan Timbulnya NegaraNegara Islam di Nusantara (Yogyakarta: LKiS, 2009).

Onghokham, Anti Cina, Kapitalisme Cina dan Gerakan Cina; Sejarah Etnis Cina di Indonesia (Depok: Komunitas Bambu, 2008).

Pals, Daniel L.,Seven Theories Of Religion Terj : Inyiak Ridwan (Jogjakarta: IRCiSoD, 2011).

Parlindungan, Mangaradja, Onggang, Tuanku Rao, (Yogyakarta : LKiS, 2007). 
Pongsibanne,Lebba, Kadorre, Islam dan Budaya Lokal (Ciputat: Mazhab Ciputat, 2013).

Ricklefs,M.C., Sejarah Indonesia Modern, Terj. Dharmono Hardjowidjono (Yogyakarta: Gadjah Mada University Press, 1995).

Suryadinata, Leo, Etnis Tionghoadan Nasionalisme Indonesia; Sebuah Bunga Rampai 1965-2008 (Jakarta: Kompas, 2010).

Suryadinata, Leo, Negara dan Etnis Tionghoa Kasus indonesia (Jakarta: LP3ES, 2002).

Susan, Blackburn, Jakarta Sejarah 400 Tahun, Terj. Gatot Triwira (Depok: Komunitas Bambu, 2012).

Zainuddin bin Abdul Aziz al-Malibari, Fathul Mu'in Jilid 1, Terj. Aliy As'ad (Kudus: Menara Kudus, 1980).

Zein, Abdul, Baqir, Etnis Cina dalam Potret Pembauran di Indonesia (Jakarta: Prestasi Insan Indonesia, 2000). 